\title{
Analisis Kelayakan Finansial Pola Tanam Berbasis Padi Gogo di Maluku
}

\section{(Analysis of Financial Feasibility of Cropping Pattern Based on Upland Rice in Maluku)}

\author{
Agung Budi Santoso ${ }^{1 \star}$, Sheny Kaihatu², Edwin Waas ${ }^{2}$ \\ (Diterima Maret 2020/Disetujui Januari 2021)
}

\begin{abstract}
ABSTRAK
Pola tanam berbasis padi gogo merupakan bentuk pola bertanam ganda atau pergiliran tanaman, yaitu padi gogo sebagai komoditas pokok (base crop) yang bisa didahului dan atau digilir dengan tanaman pangan lainnya sebagai komoditas ikutan (secondary crop). Penelitian ini dilaksanakan pada agroekosistem lahan kering di Kabupaten Kepulauan Tanimbar (Maluku Tenggara Barat), sejak bulan Maret-Desember 2017. Kajian ini merupakan penelitian adaptif (adaptive research) dengan pendekatan percobaan lapang (field experiment) di lahan petani (on farm research). Tujuan penelitian adalah untuk mendapatkan pola tanam yang paling menguntungkan, efisiensi dalam penggunaan lahan, dan efisiensi secara ekonomi serta memiliki keuntungan bersih tertinggi sehingga layak direkomendasikan sebagai inovasi teknologi pola tanam berbasis padi gogo di lahan kering. Hasil penelitian menunjukkan bahwa padi gogo ditanam secara ganda melalui tumpang sari dan atau tumpang gilir, yaitu dengan Pola Tanam Introduksi 1 yang menggunakan Padi Gogo + Jagung - Kacang Tanah dan Pola Tanam Introduksi 2 yang menggunakan Padi Gogo + Jagung/Ubikayu - Kacang Hijau - Kacang Tanah dapat meningkatkan produktivitas lahan (dengan indeks pertanaman ganda berturut-turut $222 \%$ dan $288 \%$ ) dan pendapatan petani meningkat sebesar 244-588\% dibandingkan jika dibandingkan dengan padi gogo ditanam secara monokultur. Pola bertanam ganda dapat direkomendasikan sebagai paket teknologi pola tanam berbasis padi gogo pada lahan kering karena efisiensi dalam penggunaan biaya produksi dan penggunaan lahan. Selain itu, pola tanam ini juga memberikan pendapatan usaha tani tertinggi sebesar Rp63.933.100,-/ha/tahun dengan keuntungan bersih sebesar Rp45.716.380,-/ha/tahun

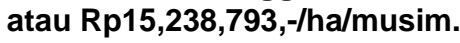

Kata kunci: padi gogo, penggunaan lahan, pola tanam, usaha tani

\section{ABSTRACT}

The upland rice-based cropping pattern is a form of double cropping or crop rotation in which upland rice as a basic commodity (base crop) which can be preceded or alternated with other food crops as a secondary crop. This study was conducted on dry land agro-ecosystems in the Tanimbar Islands Regency (West Southeast Maluku), from March to December 2017. This study was an adaptive research with a field experiment approach in farmer's land. The objective of this research was to obtain the most profitable cropping patterns, efficiency in land use and economically also has the highest net profit so it is appropriate to be recommended as a technology innovation for upland ricebased cropping patterns in dry land. The results showed that upland rice which was cultivated in multiple ways through intercropping or overlapped cropping, namely Introduced Cropping Pattern 1 (Upland Rice + Maize-Peanuts) and Introduced Cropping Pattern 2 (Upland Rice + Corn/Cassava-Green Beans-Peanuts) can increase land productivity (index planting of $222 \%$ and $288 \%$, respectively) and farmers' income increased by $244-588 \%$ compared to upland rice grown in monoculture. Multiple cropping patterns can be recommended as a technology package for upland rice-based cropping patterns on dry land because of its efficiency in the use of production costs and land use. Furthermore, it gave the highest farm income of IDR63,933,100,-/ha/year with a net profit of IDR45,716,380,/ha/year or IDR15,238,793,-/ha/ cropping season.

Keywords: cropping pattern, farming, land use, upland rice

\section{PENDAHULUAN}

Potensi ketersediaan lahan untuk pengembangan pertanian lahan kering (termasuk padi gogo) di Maluku tercatat sekitar 847.601 ha yang terdiri atas wanatani

\footnotetext{
${ }^{1}$ Balai Pengkajian Teknologi Pertanian Sumatera Utara, Jl. Jenderal Besar A.H. Nasution No.1 B, Pangkalan Masyhur, Kec. Medan Johor, Kota Medan, Sumatera Utara 20143

2 Balai Pengkajian Teknologi Pertanian Maluku, Jl. Chr. Soplanit Rumah Tiga-Ambon 97233

* Penulis Korespondensi: Email: ardenasa@gmail.com
}

(129.136 ha) dengan kemiringan lereng 9-15\% dan dataran rendah (718.465 ha) dengan kemiringan lereng 3-8 \% (Susanto \& Sirappa 2007), namun yang digunakan hanya sebagian kecil saja $305.136,40$ ha (36\%) sehingga peluang pengembangan secara ekstensifikasi masih terbuka luas, yaitu $542.464,64$ ha atau sekitar $64 \%$ dari lahan potensial. Demikian juga potensi peningkatan produksi cukup besar karena produktivitas yang dicapai di tingkat petani masih tergolong rendah. Berdasarkan data BPS Provinsi Maluku (2016), rataan produktivitas padi gogo selama 
lima tahun terakhir (2011-2015) di Maluku masih tergolong rendah (2,73 t/ha), sedangkan menurut (Fitria \& Ali 2014) potensi hasil dapat mencapai 6-7 t/ha dengan penerapan teknologi inovatif.

Pengembangan padi gogo di lahan kering dapat dilakukan baik secara tunggal (monokultur) maupun pertanaman ganda (multiple cropping). Salah satu bentuk pertanaman ganda adalah pergiliran tanaman (sequential cropping), yaitu penanaman dua atau lebih tanaman secara berurutan/bergilir pada sebidang tanah yang sama setiap tahun di mana tanaman berikutnya ditanam setelah tanaman pertama dipanen (Hidayat 2015; Arraudeau 1995).

Pola tanam berbasis padi gogo merupakan bentuk pola bertanam ganda atau pergiliran tanaman di mana padi gogo sebagai komoditas pokok (base crop) yang bisa didahului dan atau digilir dengan tanaman pangan lainnya sebagai komoditas ikutan (secondary crop). Di Maluku, padi gogo diusahakan pada agroekosistem lahan kering iklim kering (Kabupaten Maluku Tenggara, Kota Tual, Kepulauan Tanembar/Maluku Tenggara Barat dan Maluku Barat Daya) dan iklim basah (Maluku Tengah, Seram Bagian Barat, Seram Bagian Timur, Buru, dan Buru Selatan).

Petani mengusahakan padi gogo di lahan kering dengan cara yang konvensional, menerapkan pola tanam berdasarkan distribusi curah hujan dan kebiasaan setempat sesuai dengan selera masingmasing dan belum menerapkan teknologi budi daya inovatif. Pola tanam yang umum dilaksanakan adalah: Padi Gogo-Kacang Tanah/Kedelai-Bero dan atau Jagung-Kacang Tanah/Kedelai-Bero. Padi gogo dan jagung biasanya ditanam pada musim hujan, sedangkan kacang tanah dan kedelai ditanam di akhir musim hujan atau pada awal musim kemarau. Usaha tani itu berpeluang meningkatkan tidak hanya produksi padi, akan tetapi juga sejumlah komoditas palawija, seperti kacang tanah, kedelai, kacang hijau, kacang tunggak, jagung, dan ubi kayu (Purwoto 2016).

Berbagai pengkajian tentang produktivitas padi gogo menjelaskan bahwa produktivitas padi gogo tidak jauh berbeda dari padi sawah. Pengaturan pola tanam yang intensif, yakni 2-3 kali pertanaman, dapat mencapai setara gabah 15 t/ha/tahun (Husin 2007).

Hasil padi gogo dari satu kesatuan pola tanam berbasis padi gogo (tumpang sari) dapat mencapai 2.49 t/ha GKG (Sasmita et al. 2006), sedangkan dari pertanaman padi gogo tunggal (monokultur) dapat dihasilkan GKG di atas 5,0 t/ha (Idawanni et al. 2016). Dengan demikian, pengelolaan lahan kering secara intensif dan bijaksana, produksinya tidak kalah dengan lahan sawah irigasi.

Akan tetapi, analisis ekonomi pada pengembangan padi gogo masih sedikit dilakukan. Analisis ekonomi budi daya yang menjelaskan tingkat keuntungan pengembalian modal dalam usaha tani padi gogo diperlukan sebelum melakukan pengembangan padi gogo, terutama pada lahan kering. Berkenaan dengan upaya pengembangan padi gogo di lahan kering melalui analisis kelayakan usaha tani pola tanam berbasis padi gogo di Maluku, permasalahan dirumuskan sebagai berikut; (a) Manakah pola tanam berbasis padi gogo yang paling menguntungkan untuk dikembangkan di lahan kering? dan (b) Bagaimanakah pola tanam yang layak untuk direkomendasikan di lahan kering?

Sehubungan dengan permasalahan penting tersebut, penelitian bertujuan untuk mendapatkan pola tanam yang paling menguntungkan, efisiensi dalam penggunaan lahan, dan efisiensi secara ekonomi serta memiliki keuntungan bersih tertinggi di atas ambang minimum adopsi. Hasil penelitian ini akan dapat dijadikan bahan rekomendasi inovasi teknologi pola tanam dalam upaya pengembangan usaha tani berbasis padi gogo di lahan kering.

\section{METODE PENELITIAN}

\section{Pengumpulan Data}

Kajian analisis finansial pola tanam berbasis padi gogo pada agroekosistem lahan kering di Maluku dilaksanakan di Kabupaten Maluku Tenggara Barat, sejak bulan Maret-Desember 2017. Kajian ini merupakan penelitian adaptif (adaptive research) dengan pendekatan percobaan lapang (field experiment) di lahan petani (on farm research) dan pendekatan agroekosistem lahan. Lokasi pengkajian tergolong agroekosistem lahan kering dataran rendah beriklim kering.

Pengkajian menggunakan empat perlakuan yang mencakup dua pola tanam petani (eksisting), dan dua pola introduksi, adalah sebagai berikut:1) Pola tanam A: Padi gogo-Jagung-Bero, yaitu padi gogo ditanam secara monokultur setelah padi dipanen diikuti dengan jagung monokultur, kemudian dibiarkan kosong tidak ditanami (diberokan); 2) Pola tanam B: Padi gogoKacang Tanah-Bero, yaitu padi gogo ditanam secara monokultur, setelah padi gogo panen diikuti kacang tanah monokultur, kemudian lahan dibiarkan kosong tidak ditanami (diberokan); 3) Pola tanam C: Pola tanam Introduksi 1 yang menggunakan Padi gogo+ jagung-Kacang Tanah-Bero. Introduksi 1 terhadap pola petani, yaitu menerapkan pola bertanam ganda. Padi gogo ditanam secara tumpang sari dengan jagung. Setelah padi gogo dan jagung dipanen ditanami kacang tanah (monokultur), kemudian lahan dibiarkan kosong tidak ditanami (diberokan); dan 4) Pola tanam $D$, yaitu pola tanam introduksi 2 yang menggunakan Padi gogo+jagung/ubi kayu-Kacang Tanah-Kacang Hijau.

Padi gogo dan jagung ditanam secara tumpang sari, tiga minggu kemudian disisipkan ubi kayu. Setelah padi gogo dan jagung dipanen, diikuti kacang tanah kemudian kacang hijau. Peubah yang diamati meliputi: 1) Input usaha tani, yaitu biaya yang dikeluarkan untuk melaksanakan pola tanam berbasis padi gogo yang meliputi biaya saprodi (sarana produksi) dan biaya tenaga kerja, yang dinyatakan dalam Rp/ha/tahun; (2) Output usaha tani, yaitu hasil yang diperoleh setiap komoditas pada setiap pola tanam berbasis padi gogo 
dinyatakan dalam t/ha/tahun, 3) Harga input dan output di lokasi penelitian, dan 4) Produktivitas lahan.

\section{Alat Analisis Kelayakan Finansial Pola Tanam Berbasis Padi Gogo}

Ada dua analisis finansial utama yang terkait dengan permasalahan dalam penelitian, yakni (1) analisis kelayakan usaha tani dan (2) analisis kelayakan rekomendasi. Analisis kelayakan usaha tani dilakukan untuk melihat pola tanam berbasis padi gogo yang secara ekonomi menguntungkan dan layak untuk direkomendasikan di lahan kering. Sementara itu, analisis kelayakan rekomendasi ditujukan untuk mendapatkan pola tanam yang optimal untuk direkomendasikan sebagai paket teknologi usaha tani berbasis padi gogo di lahan kering. Di samping itu, digunakan analisis efisiensi penggunaan lahan menggunakan Indeks Pertanaman Ganda (IPG) mengikuti formula yang dilakukan oleh Dalrymple (1971); Andrews \& Kassam (2015):

$$
I P G=\left(\begin{array}{c}
n \mathrm{Ai}) / \mathrm{Aj}) \\
\mathrm{i}=1
\end{array} \times 100 \%(1)\right.
$$

Keterangan:

$\mathrm{IPG}=$ Indeks Pertanaman Ganda $=$ Multiple Cropping Index (MCl)

$\mathrm{N}=$ Total jumah tanaman

$\mathrm{Ai}=$ Luas lahan yang dipakai oleh tanaman ke-i dalam satu tahun

$\mathrm{Aj}=$ Total luas lahan yang tersedia untuk penanaman

Jika $=\mathrm{IPG}<100 \%=$ Produktivitas lahan rendah atau penggunaan lahan kurang efisien

IPG $>100 \%=$ Produktivitas lahan tinggi atau penggunaan lahan lebih efisien.

Analisis kelayakan usaha tani menggunakan indikator B/C (Soekartawi 2002).

$$
\mathrm{B} / \mathrm{C}=[(\mathrm{Q} \times \mathrm{Pq})-(\mathrm{TC})] / \mathrm{TC}
$$

Keterangan:

$$
\begin{array}{ll}
\mathrm{B} & =\text { Pendapatan (benefit); } \\
\mathrm{C} & =\text { Biaya (cost); } \\
\mathrm{Q} & =\text { Jumlah produksi (quantum); } \\
\mathrm{Pq} & =\text { Harga jual produk (price); }
\end{array}
$$

$\mathrm{TC}=$ Total biaya yang merupakan penjumlahan biaya tidak tetap (variable cost) dan biaya tetap (fixed cost).

Kaidah keputusan: $\mathrm{B} / \mathrm{C}=1$, usaha tani impas (tidak untung dan tidak rugi); $\mathrm{B} / \mathrm{C}>1$, usaha tani layak dan menguntungkan; $\mathrm{B} / \mathrm{C}<1$, usaha tani tidak layak dan merugi.

Analisis kelayakan rekomendasi teknologi pengelolaan tanah pada usaha tani berbasis kedelai di lahan kering melalui beberapa tahapan analisis, yaitu 1) Analisis dominan, analisis pengembalian marjinal (MRR = Margjinal Rate of Return). Analisis dominan untuk mengetahui perlakuan tidak terdominan, yaitu perlakuan yang memberikan tambahan keuntungan lebih tinggi dari setiap tambahan biaya yang dikeluarkan dan 2) Analisis tingkat pengembalian marjinal (MRR) dan residual (R) untuk menentukan perlakuan yang layak untuk direkomendasikan (Perrin dalam Ali et al. 2009). Analisis MRR dan residual dihitung dengan rumus:

$$
\begin{aligned}
& \mathrm{TPM}=(\mathrm{KBM} / \mathrm{BM}) \times 100 \%(3) \\
& \mathrm{R}=\mathrm{KB}-(\mathrm{BP} \times \min . \mathrm{ROR})(4)
\end{aligned}
$$

\section{Keterangan:}
TPM
$=$ Tingkat pengembalian marjinal
KBM
= Keuntungan bersih marjinal
$\mathrm{BM} \quad=$ Biaya marjinal
R = Residual (keuntungan bersih di atas
batas ambang minimum adopsi)
$\mathrm{KB}=$ Keuntungan bersih
$\mathrm{BP} \quad=$ Biaya produksi
Min. $\mathrm{ROR}=$ Minimum rate of return/ tingkat pengembalian minimum $(80 \%)$
yang diharapkan petani

\section{HASIL DAN PEMBAHASAN}

Pola tanam memiliki pengertian pengaturan pola pertanaman dalam sebidang lahan dengan berinteraksi pada sumber daya lahan dan teknologi yang diterapkan (Pitaloka 2018). Susunan atau urutan komoditas yang ditanam menyesuaikan kondisi sumber daya, misalnya iklim dan cuaca, sehingga tetap optimal menghasilkan pendapatan. Kondisi pola tanam juga termasuk bero yang berarti tanah atau lahan tersebut tidak ditanami untuk periode tertentu, tetapi sebelumnya ditanami dan akan ditanami kembali pada waktu yang akan datang.

Pola tanam berbasis padi gogo yang dikaji terdiri atas empat pola, yaitu: Pola tanam petani eksisiting (Pola Tanam A dan Pola Tanam B) yang hanya memiliki dua kali tanam dengan komoditas kacang tanah atau jagung setelah panen padi gogo. Dua pola lainnya (Pola Tanam C dan Pola Tanam D) ialah pola introduksi 1 dan 2. Pola introduksi 1 ialah menanam padi gogo dan jagung secara tumpang sari yang selanjutnya diikuti dengan kacang tanah. Sementara itu, pada pola introduksi 2 terjadi penambahan pola tanam dan penambahan komoditas ubi kayu dan kacang hijau.

Padi gogo merupakan komoditas utama yang menjadi basis pola tanam $A$ hingga pola tanam $D$. Perbedaan komponen teknologi pada budi daya padi gogo tersaji pada Tabel 1. Tabel 1 menjelaskan pola tanam A dan pola tanam B yang dilakukan secara monokultur, sedangkan pola tanam C ditumpangsarikan dengan jagung, dan pola tanam $\mathrm{D}$ ditumpangsarikan dengan jagung dan ubi kayu.

Pola Tanam A: Padi gogo-Jagung-Bero. Pada pola tanam ini, padi gogo Lokal Pulut Tanimbar Merah (umur panen $<90$ hari) ditanam secara monokultur 
Tabel 1 Perbandingan teknologi budi daya padi gogo dalam kegiatan pola tanam

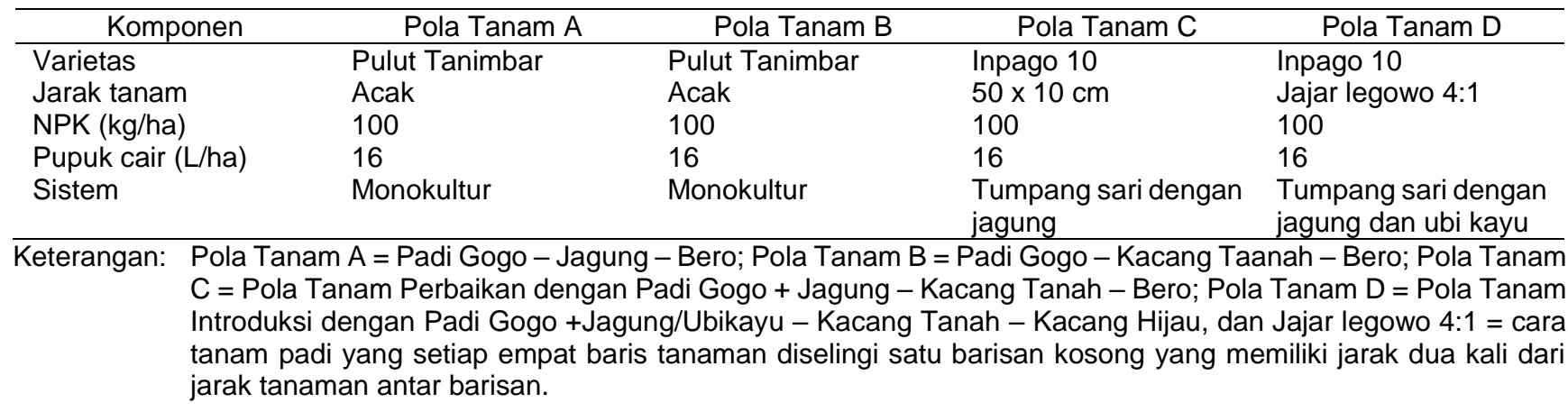

dengan jarak tanam yang tidak teratur (acak), setelah padi gogo panen diikuti dengan penanaman jagung Lokal Pulut Tanimbar secara monokultur dengan jarak tanam $100 \mathrm{~cm}$ x $100 \mathrm{~cm}$, kemudian lahan dibiarkan kosong tidak ditanami (diberokan). Pemupukan padi gogo dilakukan secara larikan takaran pupuk $100 \mathrm{~kg}$ Phonska per ha + Pupuk Cair (16 L/ha, yang diberikan 4 L/ha/aplikasi masing-masing pada umur 15 hari, 30 hari, 45 hari, dan 60 hari setelah tanam), sedangkan jagung dipupuk dengan $200 \mathrm{~kg}$ Phonska per ha + Pupuk Cair (16 L/ha, yang diberikan 4 L/ha/aplikasi masing-masing pada umur 15 hari, 30 hari, 45 hari, dan 60 hari setelah tanam). Sebelum pengolahan tanah, dilakukan pemberian herbisida (4 L/ha). Pengendalian hama baik pada padi gogo maupun jagung tidak dilakukan.

Pola Tanam B: Padi gogo-Kacang Tanah-Bero. Pada pola tanam ini, padi gogo Lokal Tanimbar Merah ditanam secara monokultur dengan jarak tanam yang tidak teratur, setelah padi dipanen diikuti dengan penanaman kacang tanah Lokal Merah secara monokultur dengan jarak tanam $40 \mathrm{~cm} \times 40 \mathrm{~cm}$, kemudian dibiarkan kosong tidak ditanami (diberokan). Pemupukan padi gogo pada Pola Tanam B ini sama dengan pemupukan pada Pola Tanam $A$, sedangkan kacang tanah tidak diberi pupuk. Sebelum pengolahan tanah, dilakukan pemberian herbisida (4 It/ha). Pengendalian hama, baik pada padi gogo maupun pada jagung tidak dilakukan.

Pola Tanam C (Pola tanam introduksi 1): Padi gogo+jagung-Kacang Tanah-Bero. Pada Pola Tanam C ini dilakukan perbaikan pada pola petani, yaitu menerapkan pola bertanam ganda dan pengaturan jarak tanam (populasi tanaman). Sebelum pengolahan tanah, dilakukan pemberian herbisida (4 L/ha). Padi varietas Inpago 10 (umur 108-116 hari) ditanam dengan jarak $50 \mathrm{~cm}$ x $10 \mathrm{~cm}$ (populasi 74\%) ditumpangsarikan dengan jagung varietas Srikandi Kuning (umur 105-110 hari) berbaris ganda, jarak tanam $400 \mathrm{~cm} \times(75 \mathrm{~cm} \times 40 \mathrm{~cm})$, dengan populasi $48 \%$. Setelah padi gogo dan jagung dipanen, kacang tanah varietas Lokal Merah ditanam secara monokultur, dengan jarak tanam $40 \mathrm{~cm}$ x $20 \mathrm{~cm}$. Sebelum pengolahan tanah untuk penanaman kacang tanah, dilakukan pemberian herbisida (4 L/ha). Setelah kacang tanah dipanen, lahan diberokan (tidak ditanami). Pemupukan padi gogo dilakukan secara larikan dan pemupukan jagung dilakukan secara tugal masing-masing dengan takaran $200 \mathrm{~kg}$ phonska per ha + Pupuk Organik Cair (8 L/ha, yang diberikan 4 It/ha/aplikasi masing-masing pada umur 30 hari dan 60 hari), yang disesuaikan dengan populasi tanaman (padi gogo 74\% dan Jagung 48\%). Sementara itu, kacang tanah (dengan populasi 100\%), dipupuk dengan $100 \mathrm{~kg}$ phonska per ha + pupuk organik cair (8 L/ha, yang diberikan 4 L/ha/aplikasi masing-masing pada umur 30 hari dan 60 hari). Pengendalian hama padi gogo dilakukan dengan pemberian karbofuran (30 $\mathrm{kg} / \mathrm{ha}$ /aplikasi) masing-masing pada saat pemupukan dasar (10 hst) dan pemupukan susulan (30 hst), kemudian diikuti dengan pemberian insektisida zat aktif bpmc (2 cc/L 4. air) apabila ada serangan. Pengendalian hama penggerek batang jagung dilakukan dengan pemberian karbofuran melalui pucuk (30 $\mathrm{kg} / \mathrm{ha}$ /aplikasi) masing-masing pada 21 hst dan 42 hst. Sementara itu, untuk pengendalian hama padi diberikan karbofuran (30 kg/ha/aplikasi) masing-masing pada saat pemupukan dasar (10 hst) dan pemupukan susulan (30 hst), kemudian diikuti dengan pemberian insektisida zat aktif bpmc (2 cc/L air) apabila ada serangan. Pengendalian hama kacang tanah dilakukan secara pemantauan (pemberian insektisida dilakukan apabila ada gejala serangan hama), dengan insektisida zat aktif bpmc (2 cc/L air).

Pola Tanam D (Pola tanam introduksi 2): Padi gogo+jagung/ubi kayu-Kacang Tanah-Kacang Hijau. Padi gogo varietas Inpago 10 ditanam dengan jarak tanam legowo 4:1 (50 cm x (25 cm x $12.5 \mathrm{~cm})$, populasi $89 \%$ ditumpangsarikan dengan jagung varietas Srikandi Kuning berbaris ganda, dengan jarak tanam $400 \mathrm{~cm} \times(75 \mathrm{~cm} \times 40 \mathrm{~cm})$ dan populasi $48 \%$. Sebelum pengolahan tanah, dilakukan pemberian herbisida (4 It/ha). Tiga minggu kemudian disisip ubi kayu di antara dalam barisan jagung dengan jarak tanam $400 \mathrm{~cm} x$ $(75 \mathrm{~cm} \times 80 \mathrm{~cm})$, dan populasi $48 \%$. Setelah padi gogo dan jagung dipanen, diikuti dengan penanaman kacang tanah varietas lokal Merah dengan jarak tanam $40 \mathrm{~cm} \times 20 \mathrm{~cm}$ dengan populasi 56\%. Sebelum pengolahan tanah untuk penanaman kacang tanah, dilakukan pemberian herbisida (4 L/ha). Setelah kacang tanah dipanen, diikuti dengan penanaman kacang hijau varietas Vima-1 dengan jarak tanam 40 $\mathrm{cm} \times 20 \mathrm{~cm}$, dengan populasi 56\%. Sebelum pengolahan tanah untuk penanaman kacang hijau, 
dilakukan pemberian herbisida (4 L/ha). Pemupukan padi gogo dan jagung dilakukan secara larikan dengan takaran $200 \mathrm{~kg}$ phonska per ha + Pupuk Organik Cair (8 L/ha, yang masing-masing diberikan $4 \mathrm{~L} /$ ha/aplikasi pada umur 30 hari dan 60 hari), yang disesuaikan dengan populasi tanaman masing-masing. Sementara itu, kacang tanah dan kacang hijau dipupuk dengan $100 \mathrm{~kg}$ phonska per ha + pupuk organik cair (8 L/ha, yang masing-masing diberikan $4 \mathrm{~L} /$ ha/aplikasi pada umur 30 hari dan 60 hari). Pengendalian hama padi gogo dilakukan dengan pemberian karbofuran (30 $\mathrm{kg} / \mathrm{ha} /$ aplikasi) masing-masing pada saat pemupukan dasar (10 hst) dan pemupukan susulan (30 hst), kemudian diikuti dengan pemberian insektisida zat aktif bpmc (2 cc/L air) apabila ada serangan. Pengendalian hama penggerek batang jagung dilakukan dengan pemberian karbofuran melalui pucuk $(30 \mathrm{~kg} / \mathrm{ha} /$ aplikasi) masing-masing pada 21 hst dan 42 hst. Pengendalian hama kacang tanah dilakukan secara pemantauan (pemberian insektisida dilakukan apabila ada gejala serangan hama), dengan insektisida zat aktif bpmc (2 cc/L air). Sementara itu, pengendalian hama kacang hijau dilakukan secara pemantauan, fase vegetatif diberikan insektisida zat aktif bpmc $(2 \mathrm{cc} / \mathrm{L}$ air $)$ dan menjelang pembungaan diberikan insektisida zat aktif deltametrin (0,5 L/ha).

\section{Analisis Efisiensi Penggunaan Lahan}

Analisis efisiensi penggunaan lahan dilakukan dengan menggunakan Indeks Pertanaman Ganda (IPG) atau Multiple Cropping Index (MCI). Jika nilai IPG $<100 \%$, produktivitas lahan rendah atau penggunaan lahan kurang efisien dan jika IPG $>100 \%$, produktivitas lahan tinggi atau penggunaan lahan lebih efisien. Hasil perhitungan IPG Pola tanam berbasis padi gogo (Tabel 2) menunjukkan bahwa teknologi pola tanam berbasis padi gogo (pola bertanam ganda) memberikan nilai IPG > 100\%, yaitu antara 200-288\%. Hasil ini menunjukkan bahwa penerapan teknologi pola tanam bertanam ganda pada usaha tani berbasis padi gogo melalui pola tumpang sari maupun pola tumpang gilir dapat meningkatkan produktivitas lahan dengan nilai IPG antara $200-288 \%$, sehingga pemanfaatan lahan lebih efisien jika dibandingkan dengan padi gogo monokultur (IPG $=100 \%$ ) jika ditanam sekali setahun. Sasmita et al. (2014) melaporkan bahwa tumpang sari antara tanaman jagung dengan tanaman kacang tanah lebih menguntungkan dibandingkan dengan sistem tanam monokultur. Sementara itu, Prasetyo et al.
(2009) melaporkan bahwa tumpang sari antara kacang tanah dan jarak pagar memberikan keuntungan sampai tiga kali lipat dibandingkan dengan bila masingmasing tanaman tersebut ditanam secara monokultur.

Pola Tanam D = Pola Tanam Introduksi 2 (Padi Gogo + Jagung/Ubikayu - Kacang Hijau - Kacang Tanah) memiliki efisiensi pemanfaatan lahan tertinggi (288\%), menyusul Pola C = Pola Tanam Introduksi 1 (Padi Gogo + jagung - Kacang Hijau) dengan efisiensi pemanfaatan lahan sebesar $222 \%$ dibandingkan dengan pola tanam monokultur (Pala Tanam A dan Pola Tanam B), seperti tersaji pada Tabel 2. Hermawati (2016) melaporkan bahwa sistem tumpang sari jagung dan tanaman legum menghasilkan efisiensi pemanfaatan lahan yang meningkat sebesar $50 \%$ dibandingkan dengan sistem monokultur. Hasil penelitian Polnaya \& Patty (2018) juga menunjukkan bahwa semua perlakuan tumpang sari antara jagung dan kacang hijau memberikan efisiensi pemanfaatan lahan yang lebih tinggi dibandingkan dengan sistem monokultur.

\section{Analisis Pendapatan dan Efisiensi Usaha Tani}

Dalam upaya menganalisis pendapatan usaha tani pada masing-masing pola tanam dilakukan penelusuran terhadap kinerja input (biaya produksi) dan output (hasil). Biaya produksi adalah semua biaya yang digunakan selama proses produksi dalam suatu sistem usaha tani, yang terdiri atas biaya sarana produksi dan biaya tenaga kerja. Keuntungan usaha tani merupakan selisih antara penerimaan/pendapatan kotor (hasil dikalikan harga pada saat panen) dan total biaya produksi dalam sistem usaha tani. Keuntungan ini merupakan pendapatan bersih yang diterima oleh petani dalam usaha tani padi gogo.

Berdasarkan analisis kebutuhan sarana produksi dan curahan tenaga kerja dapat dihitung total biaya produksi seperti tersaji pada Tabel 3. Tabel 3 menunjukkan bahwa total biaya produksi tertinggi diperoleh pada perlakuan Pola Tanam D (Pola Tanam Introduksi 2), yaitu sebesar Rp22.770.900,-/ha/tahun, menyusul perlakuan Pola Tanam C (Pola Tanam Introduksi 1), yaitu sebesar Rp16.736.400,-/ha/tahun. Sementara itu, total biaya produksi terendah (Rp12.240.000,-/ha/tahun) diperoleh pada perlakuan Pola Tanam A menyusul Pola Tanam B, Rp13.390.000,-/ha/tahun. Rendahnya biaya produksi pada Pola Tanam A dan Pola Tanam B, karena dalam setahun hanya dua kali penanaman dengan dua

Tabel 2 Indeks penggunaan lahan keempat pola tanam berbasis padi gogo di lahan kering

\begin{tabular}{cccccccc}
\hline $\begin{array}{c}\text { Perlakuan (pola } \\
\text { tanam) }\end{array}$ & Padi gogo & Jagung & $\begin{array}{c}\text { Kacang } \\
\text { tanah }\end{array}$ & $\begin{array}{c}\text { Kacang } \\
\text { hijau }\end{array}$ & Ubi kayu & Total & IPG (\%) \\
\cline { 2 - 7 } & 1,00 & 1,00 & - & - & - & 2,00 & 200 \\
Pola Tanam A & 1,00 & - & 1,00 & - & - & 2,00 & 200 \\
Pola Tanam B & 0,74 & 0,48 & 1,00 & - & - & 2,22 & 222 \\
Pola Tanam C & 0,80 & 0,48 & 0,56 & 0,56 & 0,48 & 2,88 & 288 \\
Pola Tanam D & & 0,58 &
\end{tabular}

Keterangan: Pola Tanam A = Padi Gogo - Jagung - Bero; Pola Tanam B = Padi Gogo - Kacang Taanah - Bero; Pola Tanam C = Pola Tanam Perbaikan dengan Padi Gogo + Jagung - Kacang Tanah - Bero; Pola Tanam D = Pola Tanam Introduksi dengan Padi Gogo +Jagung/Ubikayu - Kacang Tanah - Kacang Hijau; dan IPG = Indek Pertanaman Ganda. 
Tabel 3 Total biaya produksi keempat pola tanam berbasis padi gogo di lahan kering

\begin{tabular}{crcc}
\hline \multirow{2}{*}{ Perlakuan (Pola tanam) } & Biaya saprodi & Biaya tenaga kerja & Total biaya produksi \\
\cline { 2 - 4 } & & $\ldots \ldots \ldots \ldots \ldots$ & 12.240 .000 \\
Pola Tanam A & 6.490 .000 & 5.750 .000 & 13.390 .000 \\
Pola Tanam B & 7.440 .000 & 6.250 .000 & 16.736 .400 \\
Pola Tanam C & 9.636 .400 & 7.100 .000 & 22.770 .900 \\
Pola Tanam D & 13.320 .900 & 9.450 .000 & $\ldots \ldots \ldots$ \\
\hline
\end{tabular}

Keterangan: Pola Tanam A = Padi Gogo - Jagung - Bero; Pola Tanam B = Padi Gogo - Kacang Taanah - Bero; Pola Tanam C = Pola Tanam Perbaikan dengan Padi Gogo + Jagung - Kacang Tanah - Bero; dan Pola Tanam D = Pola Tanam Introduksi dengan Padi Gogo +Jagung/Ubikayu - Kacang Tanah - Kacang Hijau.

Tabel 4 Produksi (hasil bersih) dan penerimaan keempat pola tanam berbasis padi gogo di lahan kering (dalam 1 ha)

\begin{tabular}{ccccccc}
\hline \multirow{2}{*}{ Perlakuan } & \multicolumn{7}{c}{ Hasil bersih (t/ha) } & \begin{tabular}{c} 
Padi \\
\cline { 2 - 6 }
\end{tabular} & $\begin{array}{c}\text { Jagung } \\
\text { (Biji Pipilan } \\
\text { Kering) }\end{array}$ & $\begin{array}{c}\text { Kacang Tanah } \\
\text { (Polong Kering) }\end{array}$ & $\begin{array}{c}\text { Kacang Hijau } \\
\text { (Biji Kering) }\end{array}$ & $\begin{array}{c}\text { Ubi Kayu } \\
\text { (Umbi } \\
\text { Segar) }\end{array}$ & $\begin{array}{c}\text { Penerimaan } \\
\text { (Rp/ha/tahun) }\end{array}$ \\
\hline Pola Tanam A & 1.225 & 3.142 & - & - & - & 21.676 .000 \\
Pola Tanam B & 1.111 & - & 1.167 & - & - & 46.120 .000 \\
Pola Tanam C & 0.811 & 2.167 & 1.187 & - & - & 50.221 .000 \\
Pola Tanam D & 0.952 & 1.972 & 0.901 & 1.341 & 5.806 & 86.704 .000 \\
\hline
\end{tabular}

Keterangan: Pola Tanam A menggunakan Padi Gogo - Jagung - Bero, Pola Tanam B menggunakan Padi Gogo - Kacang Tanah - Bero, Pola Tanam C adalah Pola Tanam Introduksi 1 yang menggunakan Padi Gogo + Jagung Kacang Tanah - Bero, dan Pola Tanam D adalah Pola Tanam Introduksi 2 yang menggunakan Padi Gogo +Jagung/Ubikayu - Kacang Tanah - Kacang Hijau.

komoditas (IP = 200), sehingga curahan tenaga kerja dan biaya sarana produksi adalah rendah (tanpa pengendalian hama/penyakit).

Hasil yang diperoleh dari keempat pola tanam tersebut disajikan pada Tabel 4 . Tabel 4 menunjukkan bahwa hasil padi gogo pada Pola Tanam A dan Pola Tanam B yang ditanam secara monokultur lebih tinggi dibandingkan dengan Pola Tanam $\mathrm{C}$ dan Pola Tanam $D$ yang ditanam secara tumpang sari, karena populasi padi monokultur (Pola Tanam A dan Pola Tanam B) adalah $100 \%$, sedangkan pola tumpang sari hanya 74\% (Pola Tanam C) dan 89\% (Pola Tanam D). Demikian juga jagung yang ditanam secara monokultur (Pola Tanam A) memberikan hasil yang lebih tinggi, karena populasi $100 \%$ dibandingkan dengan jagung tumpang sari, populasi $48 \%$ (Pola Tanam C dan Pola Tanam D). Di samping itu, kacang tanah monokultur yang ditanam setelah padi gogo monokultur (Pola Tanam B) maupun padi gogo tumpang sari dengan jagung (Pola Tanam $\mathrm{C}$ ) memberikan hasil yang lebih tinggi (populasi $100 \%$ ) dibandingkan dengan kacang tanah tumpang sari (Pola Tanam D, populasi 56\%). Sementara itu, kacang hijau merupakan tanaman urutan ketiga yang ditanam setelah panen padi gogo dan jagung (Pola Tanam D), namun karena ubi kayu belum dipanen sehingga populasi kacang hijau hanya $56 \%$ dengan hasil 1.341 ton biji kering per ha (Tabel 4). Penerimaan (pendapatan kotor) adalah total hasil setiap komoditas yang diperoleh dikalikan harga pada saat penelitian, yang dinyatakan dalam Rp/ha/tahun. Harga penjualan hasil pada saat panen di Kabupaten Maluku Tenggara Barat adalah sebagai berikut; hasil padi gogo dinyatakan dalam bentuk beras $(60 \% \mathrm{x}$ GKG = Gabah kering Giling) dengan harga Rp10.000,- /kg; hasil jagung (biji pipilan kering) Rp3.000,-/kg; kacang tanah (polong kering) Rp30.000,-/kg; kacang hijau (biji kering) Rp20.000,-/kg; dan ubi kayu (umbi segar) Rp3.000,-/kg.

Tabel 4 menunjukkan bahwa Pola Tanam D memberikan penerimaan tertinggi sebesar Rp86.704.000,/ha/tahun menyusul Pola Tanam C sebesar Rp50.221.000,-/ha/tahun. Tingginya penerimaan pada Pola Tanam D karena satu ha dalam setahun ditanam lima komoditas secara tumpang sari dan tumpang gilir. Sementara itu, Pola Tanam A (Pola Petani A = Padi gogo - jagung) memberikan hasil terendah menyusul Pola Tanam B (Pola Petani B = Padi gogo - Kacang Tanah), di mana satu ha dalam setahun hanya ditanam dua komoditas secara monokultur.

Pendapatan/keuntungan bersih adalah penerimaan (pendapatan kotor) dikurangi biaya produksi. Biaya produksi yang rendah atau penerimaan tertinggi belum tentu memberikan pendapatan tertinggi. Akan tetapi, penerimaan (pendapatan kotor) tertinggi dengan biaya produksi terendah akan memberikan pendapatan (keuntungan bersih) tertinggi. Tabel 4 menunjukkan bahwa pada perlakuan Pola Tanam D (Pola Tanam Introduksi 2) memberikan pendapatan tertinggi sebesar Rp63.933.100,-/ha/tahun, menyusul perlakuan Pola Tanam C (Pola Tanam Introduksi 1) dan Pola Tanam B. Sementara itu, total biaya produksi terendah (Rp9.436.000,-/ha/tahun) diperoleh pada perlakuan Pola Tanam A. Pola Tanam D (Pola Tanam Introduksi 2) walaupun total biaya produksi yang dikeluarkan adalah tinggi, hasil yang diperoleh juga tinggi sehingga pendapatan yang diterima petani adalah tertinggi (Rp63.933.100,-/ha) dan diikuti oleh 
perlakuan Pola Tanam C (Pola Tanam Introduksi 1) dan Pola Tanam B.

Selanjutnya, untuk menilai efisiensi ekonomi Pola Tanam Berbasis Padi Gogo digunakan nisbah B/C ratio, yaitu jumlah produksi dikalikan harga jual produk (price) dikurangi total biaya produksi dibagi total biaya produksi. Suatu sistem usaha tani dikatakan efisien dalam penggunaan biaya produksi apabila nilai $\mathrm{B} / \mathrm{C}$ > 1, sehingga menguntungkan.

Efisiensi ekonomi Pola Tanam Berbasis Padi Gogo di lahan kering tersaji pada Tabel 5. Tabel 5 menunjukkan bahwa Pola Tanam A secara monokultur kurang efisien secara ekonomi $(B / C=0,77)$, dibandingkan dengan Pola Tanam B, Pola Tanam C (Pola Tanam Introduksi 1), dan Pola Tanam D (Pola Introduksi 2) yang lebih efisien dengan nilai $B / C>1$.

Berdasarkan analisis pendapatan/keuntungan bersih dan efisiensi ekonomi tersebut di atas, Pola Tanam B, Pola Tanam C, dan Pola Tanam D dapat direkomendasikan sebagai Pola Tanam berbasis padi gogo di lahan kering beriklim kering Maluku. Selanjutnya, untuk mengetahui pola tanam yang akan direkomendasikan kepada petani pengguna, perlu dilakukan analisis kelayakan rekomendasi.

\section{Analisis Kelayakan Rekomendasi}

Analisis kelayakan rekomendasi teknologi pola tanam berbasis padi gogo di lahan kering meliputi analisis dominan, analisis tingkat pengembalian marjinal, dan analisis residual (Soekartawi 2002; Perrin $d$ alam Ali et al. 2009 ).

Analisis dominan untuk mengetahui perlakuan terdominasi, yaitu perlakuan yang memberikan tamba- han pendapatan/keuntungan bersih yang lebih tinggi d ari setiap tambahan biaya yang dikeluarkan. Hasil analisis dominan pada Tabel 6 menunjukkan uji dominan terhadap Pola Tanam A. Hasilnya menunjukkan bahwa ketiga perlakuan selain Pola Tanam A tidak terdominasi karena keseluruhan perlakuan atau pola tanam menunjukkan nilai tambahan biaya yang lebih kecil dibandingkan dengan tambahan pendapatan. Hal ini menjelaskan bahwa setiap satu rupiah yang ditambahkan dengan perbandingan Pola Tanam A, menghasilkan tambahan pendapatan lebih dari satu rupiah. Jika dilihat dari TPM, maka pengembalian terbesar ditemukan pada Pola Tanam B, yakni pengembalian sebesar Rp15.

Tabel 7 menjelaskan analisis dominan dengan menggunakan Pola Tanam B sebagai acuan. Terlihat bahwa pola introduksi 1 (Pola Tanam C) terdominasi karena memiliki nilai tambahan biaya yang lebih besar dibandingkan dengan tambahan pendapatan. Hal ini menunjukkan bahwa Pola Tanam C tidak ekonomis dilakukan jika petani telah menerapkan Pola Tanam B.

Berbeda halnya dari Pola Tanam D yang memiliki nilai TPM yang lebih dari 1 yang menandakan bahwa pengembalian pendapatan lebih besar dibandingkan dengan tambahan biaya yang dikeluarkan. Nilai TPM sebesar 3.47 mengartikan bahwa setiap Rp1 yang dikeluarkan dalam perpindahan Pola Tanam B ke Pola Tanam D, menghasilkan pengembalian pendapatan sebesar Rp3.47. Hal ini menandakan bahwa Pola Tanam D secara ekonomis menguntungkan dan layak dikembangkan, meskipun petani telah mengusahakan Pola Tanam $B$ yang memiliki keuntungan yang lebih besar dibandingkan dengan Pola Tanam A.

Tabel 5 Efisiensi ekonomi pola tanam berbasis padi gogo di lahan kering

\begin{tabular}{|c|c|c|c|c|c|c|}
\hline \multirow[t]{2}{*}{$\begin{array}{l}\text { Perlakuan } \\
\text { (pola tanam) }\end{array}$} & Total penerimaan & Biaya produksi & Pendapatan & \multicolumn{2}{|c|}{$\begin{array}{c}\text { Peningkatan } \\
\text { pendapatan terhadap } \\
(\%)\end{array}$} & \multirow[t]{2}{*}{$\begin{array}{c}\text { Efisiensi } \\
\text { ekonomi }(B / C)\end{array}$} \\
\hline & \multicolumn{3}{|c|}{$\ldots \ldots \ldots \ldots \ldots \ldots . . . . \mathrm{Rp} /$ ha/tahun............. } & Pola A & Pola B & \\
\hline Pola Tanam A & 21.676 .000 & 12.240 .000 & 9.436 .000 & - & - & 0,77 \\
\hline Pola Tanam B & 46.120 .000 & 13.690 .000 & 32.430 .000 & 244 & - & 2,37 \\
\hline Pola Tanam C & 50.221 .000 & 16.736 .400 & 33.484 .600 & 255 & 3 & 2,00 \\
\hline Pola Tanam D & 86.704 .000 & 22.770 .900 & 63.933 .100 & 578 & 97 & 2,81 \\
\hline
\end{tabular}

Keterangan: Pola Tanam A menggunakan Padi Gogo - Jagung - Bero, Pola Tanam B menggunakan Padi Gogo - Kacang Tanah - Bero, Pola Tanam C adalah Pola Tanam Introduksi 1 yang menggunakan Padi Gogo + Jagung Kacang Tanah - Bero, dan Pola Tanam D adalah Pola Tanam Introduksi 2 yang menggunakan Padi Gogo +Jagung/Ubikayu - Kacang Tanah - Kacang Hijau.

Tabel 6 Analisis dominan dan analisis marjinal untuk keempat pola tanam berbasis padi gogo dengan acuan Pola Tanam A.

\begin{tabular}{|c|c|c|c|c|c|c|}
\hline \multirow[b]{2}{*}{$\begin{array}{c}\text { Perlakuan (Pola } \\
\text { tanam) }\end{array}$} & \multirow[b]{2}{*}{$\begin{array}{l}\text { Total biaya } \\
\text { produksi }\end{array}$} & \multirow{2}{*}{$\begin{array}{l}\text { Pendapatan/ } \\
\text { keuntungan } \\
\text { bersih }\end{array}$} & \multicolumn{2}{|c|}{ Perubahan *) } & \multirow[b]{2}{*}{$\begin{array}{c}\text { Ter- } \\
\text { dominasi }\end{array}$} & \multirow{3}{*}{$\begin{array}{c}\left.\mathrm{TPM}^{\star *}\right) \\
(\%)\end{array}$} \\
\hline & & & KBM & BM & & \\
\hline \multicolumn{6}{|c|}{............Rp/ha/tahun................ } & \\
\hline Pola Tanam A & 12.240 .000 & 9.436 .000 & - & - & - & - \\
\hline Pola Tanam B & 13.690 .000 & 32.430 .000 & 22.994 .000 & 1.450 .000 & Tidak & 15,9 \\
\hline Pola Tanam C & 16.736 .400 & 33.484 .600 & 24.048 .600 & 4.496 .400 & Tidak & 5,3 \\
\hline Pola Tanam D & 22.770 .900 & 63.933 .100 & 54.497 .100 & 10.530 .900 & Tidak & 5,1 \\
\hline
\end{tabular}

Keterangan: Pola Tanam A menggunakan Padi Gogo - Jagung - Bero, Pola Tanam B menggunakan Padi Gogo - Kacang Tanah - Bero, Pola Tanam C adalah Pola Tanam Introduksi 1 yang menggunakan Padi Gogo + Jagung Kacang Tanah - Bero, dan Pola Tanam D adalah Pola Tanam Introduksi 2 yang menggunakan Padi Gogo +Jagung/Ubikayu - Kacang Tanah - Kacang Hijau. *) Perubahan tertinggi sebelumnya, KBM = Keuntungan bersih marjinal, BM = Biaya Marjinal, dan TPM = Tingkat pengembalian marjinal. 
Tabel 7 Analisis dominan dan analisis marjinal untuk keempat pola tanam berbasis padi gogo dengan acuan Pola Tanam B

\begin{tabular}{|c|c|c|c|c|c|c|}
\hline \multirow{3}{*}{$\begin{array}{l}\text { Perlakuan } \\
\text { (Pola tanam) }\end{array}$} & \multirow[b]{2}{*}{$\begin{array}{l}\text { Total biaya } \\
\text { produksi }\end{array}$} & \multirow{2}{*}{$\begin{array}{l}\text { Pendapatan/ } \\
\text { keuntungan } \\
\text { bersih }\end{array}$} & \multicolumn{2}{|c|}{ Perubahan *) } & \multirow[b]{2}{*}{$\begin{array}{c}\text { Ter- } \\
\text { dominasi }\end{array}$} & \multirow{3}{*}{$\begin{array}{c}\left.\mathrm{TPM}^{\star *}\right) \\
(\%)\end{array}$} \\
\hline & & & KBM & BM & & \\
\hline \multirow{2}{*}{\multicolumn{7}{|c|}{$\begin{array}{c}\ldots \ldots \ldots \ldots \text { Rp/ha/tahun } \ldots \ldots \ldots \ldots \ldots \\
9.436 .000\end{array}$}} \\
\hline & & & & & & \\
\hline Pola Tanam B & 13.690 .000 & 32.430 .000 & - & - & - & - \\
\hline Pola Tanam C & 16.736 .400 & 33.484 .600 & 1.054 .600 & 3.046 .400 & $\mathrm{Ya}$ & 0,35 \\
\hline Pola Tanam D & 22.770 .900 & 63.933 .100 & 54.497 .100 & 9.080 .900 & Tidak & 3,47 \\
\hline
\end{tabular}

Keterangan: Pola Tanam A menggunakan Padi Gogo - Jagung - Bero, Pola Tanam B menggunakan Padi Gogo - Kacang Tanah - Bero, Pola Tanam C adalah Pola Tanam Introduksi 1 yang menggunakan Padi Gogo + Jagung Kacang Tanah - Bero, dan Pola Tanam D adalah Pola Tanam Introduksi 2 yang menggunakan Padi Gogo +Jagung/Ubikayu - Kacang Tanah - Kacang Hijau. *) Perubahan tertinggi sebelumnya, KBM = Keuntungan Bersih Marjinal, BM = Biaya Marjinal, dan TBM = Tingkat Pengembalian Marjinal.

Tabel 8 Analisis residual untuk keempat pola tanam berbasis padi gogo

\begin{tabular}{ccccr}
\hline $\begin{array}{c}\text { Perlakuan } \\
\text { (Pola tanam) }\end{array}$ & $\begin{array}{c}\text { Total biaya } \\
\text { produksi }\end{array}$ & $\begin{array}{c}\text { Pendapatan/ } \\
\text { keuntungan bersih }\end{array}$ & $\begin{array}{c}\text { Keuntungan yang } \\
\text { diharapkan }\end{array}$ & Residual $^{* \star}$ ) \\
\cline { 2 - 5 } & & $\ldots \ldots \ldots \ldots \ldots \ldots$ Rp/ha/tahun .............. & 356.000 \\
Pola Tanam A & 12.240 .000 & 9.436 .000 & 9.792 .000 & 21.478 .000 \\
Pola Tanam B & 13.690 .000 & 32.430 .000 & 10.952 .000 & 20.095 .480 \\
Pola Tanam C & 16.736 .400 & 33.484 .600 & 13.389 .120 & 45.716 .380 \\
Pola Tanam D & 22.770 .900 & 63.933 .100 & 18.216 .720 & \\
\hline
\end{tabular}

Keterangan: Pola Tanam A menggunakan Padi Gogo - Jagung - Bero, Pola Tanam B menggunakan Padi Gogo - Kacang Tanah - Bero, Pola Tanam C adalah Pola Tanam Introduksi 1 yang menggunakan Padi Gogo + Jagung Kacang Tanah - Bero, dan Pola Tanam D adalah Pola Tanam Introduksi 2 yang menggunakan Padi Gogo +Jagung/Ubikayu - Kacang Tanah - Kacang Hijau. *) 80\% (tingkat pengembalian minimum) x biaya produksi dan $\left.^{* \star}\right)$ Residual $=$ Keuntungan Bersih $-(80 \%$ x Biaya Produksi $)$.

Menurut Perrin et al. (1976), rekomendasi yang dianjurkan sebaiknya juga didasarkan pada batasan tingkat kembali minimum (minimum rate of return) yang mungkin dapat diterima oleh petani di daerah rekomendasi dan keuntungan bersih di atas ambang mininum adopsi (Residual). Dijelaskan lebih lanjut bahwa tingkat kembali minimum yang diterima petani adalah antara $50-100 \%$. Jika teknologi yang akan direkomendasikan kepada petani merupakan teknologi baru dan membutuhkan keterampilan khusus, nilai $50 \%$ adalah layak. Dalam penelitian ini, tingkat pengembalian minimum digunakan $80 \%$, dengan pertimbangan bahwa teknologi yang digunakan bukan merupakan teknologi baru dan tidak membutuhkan keterampilan khusus.

Selanjutnya untuk menghitung perlakuan Pola Tanam yang akan direkomendasikan, hasil MRR tersebut perlu dipertimbangkan adanya batas minimum penerimaan petani untuk kegiatan yang memerlukan biaya yang disebut "residual". Analisis residual yang tersaji pada Tabel 7 menunjukkan bahwa keuntungan bersih di atas ambang minimum adopsi (residual) tertinggi sebesar Rp45.716.380/ha/tahun diperoleh pada Pola Tanam D (Pola Tanam Introduksi 2), menyusul Pola Tanam B dan Pola Tanam C (Pola Tanam Introduksi 1). Sementara itu, residual yang dicapai pada Pola Tanam A adalah negatif, sehingga tidak direkomendasikan. Di samping itu, Pola Tanam B walaupun tingkat pengembalian marjinal lebih tinggi (Tabel 6) dibandingkan dengan Pola Tanam D, nilai residualnya lebih rendah (Tabel 8) sehingga Pola Tanam D (Pola Tanam Introduksi 2) merupakan pola yang dapat direkomendasikan sebagai Pola Tanam berbasis padi gogo di lahan kering.

\section{KESIMPULAN}

Padi gogo yang ditanam mengikuti Pola Tanam $A$ (Padi Gogo-Jagung) maupun Pola Tanam B (Padi gogo-Kacang Tanah) memberikan pendapatan usaha tani dan produktivitas lahan yang lebih rendah dibandingkan dengan Pola Tanam Introduksi 1 (Padi + Jagung - Kacang Tanah) dan Pola Tanam Introduksi 2 (Padi Gogo + Jagung/Ubi Kayu - Kacang Tanah Kacang Hijau).

Pola Tanam Introduksi 2 merupakan pola tanam yang dapat direkomendasi sebagai inovasi teknologi usaha tani berbasis padi gogo di lahan kering karena memberikan pendapatan tertinggi sebesar Rp63.933.100,-/ha/tahun), memiliki efisiensi dalam penggunaan/pemanfaatan lahan dengan nilai IPG > $100 \%(288 \%)$ dan efisiensi secara ekonomi nilai B/C > $1(2,81)$, serta memiliki tingkat pengembalian marjinal dan nilai residual (keuntungan bersih di atas ambang adopsi) yang diperoleh tertinggi.

\section{DAFTAR PUSTAKA}

Ali M, Costa DJM, Abedin M, Sayed, N Basak. 2009. Effect of Fertilizer and Variety on The Yield of Sweet Potato. Jurnal Agril 34: 473-480. https://doi.org/ 10.3329/bjar.v34i3.3974 
Andrews DJ, Kassam AH. 2015. The Importance of Multiple Cropping in Increasing World Food Supplies. Multiple Cropping. 1-10. https:// doi.org/10.2134/ asaspecpub27.c1

Arraudeau MA. 1995. Upland Rice: Challenges and Opportunities in a Less Favorable Ecosystem. Geo Journal. 35(3): 325-328. https://doi.org/10. 1007/BF00989139

Dalrymple DG. 1971. Survey of Multiple Cropping in Less Developed Nations. Washington: Economic Research Service.

Fitria, Eka, Ali MN. 2014. Kelayakan Usahatani Padi Gogo Dengan Pola Pengelolaan Tanaman Terpadu (PTT) Di Kabupaten Aceh Besar, Provinsi Aceh. Widyariset. 17(3): 425-434.

Hermawati T, Diah. 2016. Kajian Ekonomi Antara Pola Tanam Monokultur dan Tumpangsari. Inovasi XVIII(1): 66-71.

Hidayat, Jan R. 2015. Perluasan Areal Padi Gogo Sebagai Pilihan Untuk Mendukung Ketahanan Pangan Nasional. Iptek Tanaman Pangan. 2(1): 26-40.

Husin M, Toha. 2007. Peningkatan Produktivitas Padi Gogo Melalui Penerapan Pengelolaan Tanaman Terpadu Dengan Introduksi Varietas Unggul. Penelitian Pertanian Tanaman Pangan. 26(3): 180 87.

Idawanni, Hasanuddin, Bakhtiar. 2016. Uji Adaptasi Beberapa Varietas Padi Gogo di Antara Tanaman Kelapa Sawit Muda Di Kabupaten Aceh Timur. Jurnal Floratek. 11(2): 88-95.

Pitaloka, Dyah. 2018. Lahan Kering Dan Pola Tanam Untuk Mempertahankan Kelestarian Alam. Jurnal
Teknologi Terapan: G-Tech. 2(1): 119-126. https://doi.org/10.33379/gtech.v2i1.329

Polnaya, Febby, Patty J. 2018. Kajian Pertumbuhan Dan Produksi Varietas Jagung Lokal dan Kacang Hijau Dalam Sistem Tumpangsari. Agrologi. 1(1): 42-51. https://doi.org/10.30598/a.v1i1.297

Prasetyo, Entang I, Hesti P. 2009. Produktivitas Lahan dan NKL Pada Tumpang Sari Jarak Pagar Dengan Tanaman Pangan. Jurnal Akta Agrosia. 12(1): 5155.

Purwoto, Adreng. 2016. Analisis Usahatani Padi dan Palawija Pada Lahan Kering di Kalimantan Selatan: Studi Kasus di Desa Budi Mulia, Kabupaten Tapin. Forum Penelitian Agro Ekonomi. 7(2): 32. https://doi.org/10.21082/fae.v7n2.1989.32-41

Sasmita, Inggit, Supriyono, Sri N. 2014. Pengaruh Berbagai Varietas Jagung Secara Tumpangsari Additive Series Pada Pertanaman Kacang Tanah Terhadap Pertumbuhan dan Hasil. Journal of Chemical Information and Modeling. 53(9): 1689$1699 . \quad$ https://doi.org/10.20961/carakatani. v29i1.13312

Sasmita, Priatna, Bambang S. Purwoko, and S. Sujiprihati. 2006. Evaluasi Pertumbuhan dan Produksi Padi Gogo Haploid Ganda Toleran Naungan Dalam Sistem Tumpang Sari. Jurnal Agronomi Indonesia. 34(2): 79-86.

Soekartawi. 2002. Analisis Usahatani. Jakarta (ID): UI Press.

Susanto, Noto A, Sirappa MP. 2007. Karakteristik dan Ketersediaan Data Sumber Daya Lahan PulauPulau Kecil Untuk Perencanaan Pembangunan Pertanian di Maluku. Jurnal Litbang Pertania. 26(2): 41-53. 